\title{
SEBARAN SPASIAL LOGAM Pb, Cd, Cu, Zn DAN FRAKSI GEOKIMIA DI SEDIMEN PERAIRAN PANTAI KOTA MAKASSAR
}

\section{Spatial Distribution of $\mathrm{Pb}, \mathrm{Cd}, \mathrm{Cu}, \mathrm{Zn}$ and the Geochemical Fractions in the Sediment of Makassar City Coastal Waters}

\author{
Shinta Werorilangi ${ }^{1 *}$, Alfian Noor ${ }^{2}$, M. Farid Samawi ${ }^{1}$, Ahmad Faizal $^{1}$, \\ Akbar Tahir ${ }^{1}$
}

Diterima: 3 Juli 2019 Disetujui: 10 Juli 2019

\begin{abstract}
ABSTRAK
Perairan pantai Kota Makassar, termasuk dua muara sungai yang mengapit, yaitu Sungai Jeneberang dan Sungai Tallo banyak mendapat inputan logam dari badan sungai dan dari daratan utama, berupa limbah industri dan limbah perkotaan. Penelitian ini bertujuan untuk menentukan distribusi spasial konsentrasi $\mathrm{Pb}, \mathrm{Cd}, \mathrm{Cu}$, dan $\mathrm{Zn}$ serta fraksi bioavailable di sedimen perairan pantai Kota Makassar. Penelitian dilakukan di wilayah perairan pantai Kota Makassar, mulai dari muara Sungai Jeneberang hingga muara Sungai Tallo. Pengukuran logam dilakukan pada sedimen berukuran $<63 \mu \mathrm{m}$. Spesiasi logam pada fraksi sedimen ditentukan dengan metode Community Bureau of Reference (BCR) Threesteps Sequential method yang menghasilkan fraksi exchangeable dan acid soluble, reducible, serta oxidisable. Interpolasi sebaran spasial logam di sedimen dilakukan dengan menggunakan teknik Sistem Informasi Geografis (SIG) yaitu block kriging (BK) dengan program Arc View. Sebaran logam sangat ditentukan oleh input atau sumber dari daratan dimana sebaran spasial logam $\mathrm{Pb}, \mathrm{Cd}, \mathrm{Cu}$, dan $\mathrm{Zn}$ di sedimen meningkat ke arah utara pantai Kota Makassar. Sebaran spasial fraksi 1 (terlarut dalam asam, acid reducible) logam $\mathrm{Pb}$ dan $\mathrm{Cu}$ tidak berbanding lurus dengan sebaran konsentrasi totalnya di sedimen. Sedangkan sebaran spasial fraksi 1 logam $\mathrm{Cd}$ dan $\mathrm{Zn}$ berbanding lurus dengan sebaran konsentrasi totalnya di sedimen.
\end{abstract}

Kata kunci : sebaran, spasial, logam, spesiasi, sedimen, pantai, Makassar

\begin{abstract}
Coastal waters of Makassar, including two estuaries of Jeneberang River and Tallo River, received many inputs of metals from the water body and the mainland, in the form of industrial and municipal wastes. This study aims to determine the spatial distribution of $\mathrm{Pb}, \mathrm{Cd}, \mathrm{Cu}$, and $\mathrm{Zn}$ total concentration, and their geochemical fractions of coastal sediments of Makassar City. The study was conducted in the coastal waters of Makassar, from estuary of Jeneberang River to estuary of Tallo River. All metals analysis for sediment were conducted with dry, <63 $\mu \mathrm{m}$ grain size sediment samples. Metal speciation of bioavailable fractions in sediment was determined using the BCR (Community Bureau of Reference) three-step sequential that extract exchangeable and acid soluble fraction, reducible fraction, and oxidizable fraction. Spatial distribution of metals in the sediments was interpolated by using Geographical Information System $(G I S)$, the block kriging (BK) with Arc View computer program. The spatial distribution of total concentration of $P b$, $\mathrm{Cd}, \mathrm{Cu}$, and $\mathrm{Zn}$ in sediments increases towards the north coast of Makassar. Spatial distribution pattern of Pb and $\mathrm{Cu}$ in the fraction 1(acid reducible, most bioavailable) is not directly proportional to the spatial distribution of total concentration in sediments. While the spatial distribution of $\mathrm{Cd}$ and $\mathrm{Zn}$ in fraction 1 is proportional to the distribution of total concentration in the sediment.
\end{abstract}

Keywords : distribution, spatial, metal, speciation, coastal, sediment, Makassar

\section{PENDAHULUAN}

Logam yang masuk ke lingkungan perairan pada akhirnya akan terakumulasi di sedimen. Pada saat terakumulasi di sedimen, logam dapat diserap oleh biota bentik dan pada akhirnya akan masuk dalam rantai makanan. Potensi bahaya akibat pemaparan logam pada biota selalu diasosiasikan dengan

\section{Korespondensi:}

Shinta Werorilangi $1^{*}$

E-mail: shintakristanto@yahoo.com

${ }^{1}$ Departemen Ilmu Kelautan, FIKP Universitas

Hasanuddin, Makassar

${ }^{2}$ Departemen Kimia, F MIPA, Universitas Hasanuddin konsentrasi total logam pada media. Sudah banyak penelitian yang membuktikan bahwa konsentrasi total logam untuk penentuan toksisitas logam baik esensial maupun yang non-esensial tidak selamanya berkorelasi positif dengan dampak negatif yang terjadi pada biota (Hendozko et al. ; Cunha et al., 20082010Stauber et al., 2005). Pada saat logam berada di lingkungan perairan dan sebelum diserap oleh biota, logam akan berpartisi antara fase cair dan fase padat yang selama proses partisi tersebut sangat dipengaruhi oleh faktor fisik dan kimia perairan. Studi tentang bioavailibilitas logam di perairan menunjukkan bahwa logam dalam bentuk ion bebas yang sangat mudah diserap oleh biota. Pada saat logam berada pada fase solid, yaitu di 
sedimen, logam akan berpartisi pada fraksi-fraksi geokimia di sedimen, yang pada akhirnya akan menentukan bioavailabilitasnya bagi biota. Fraksi geokimia yang bioavailable di sedimen akan menentukan seberapa besar logam akan terserap oleh organisme, bioakumulasinya dan dampak toksisitasnya pada organisme khususnya bentik (Paller and Knox, 2013).

Perairan pantai kota Makassar terletak diantara dua sungai besar, yaitu Sungai Jeneberang di daerah selatan dan Sungai Tallo di bagian utara. Kedua sungai tersebut serta beberapa kanal kota memberikan inputan logam yang berasal dari limbah perkotaan dan limbah industri. Data konsentrasi total logam kadmium (Cd) di perairan kota Makassar menunjukkan tren yang meningkat dari tahun 2005 hingga 2008 (Samawi, 2007; Bapedalda Pemprov Sulsel, 2007 dan 2008). Konsentrasi total logam timbal $(\mathrm{Pb})$ di sedimen perairan kota Makassar pada titik tertentu seperti muara Sungai Tallo menunjukkan nilai yang sangat tinggi pada tahun 2006-2007, yaitu sekitar 18,01$27,33 \mathrm{mg} \mathrm{kg}^{-1}$; sedangkan di sekitar pantai Losari pada tahun 2008 sebesar 4,77 $\mathrm{mg} \mathrm{kg}^{-1}$; dan di sedimen Pulau Lae-Lae yang berjarak sekitar $1 \mathrm{~km}$ dari Kota Makassar, konsentrasi total Pb sekitar $11,95 \mathrm{mg} \mathrm{kg}-1$ pada tahun 2011 (Roem, 2007; Widyasari, 2007; Wulandari, 2008; Rizal, 2011).

Hasil penelitian Werorilangi et al. (2013), menunjukkan lokasi yang mendapat input antropogenik yang tinggi yaitu di sekitar pelabuhan rakyat Paotere dan Kanal Benteng. Fraksi bioavailable (yang mudah diserap oleh biota) juga ditemukan di sedimen daerah tersebut. Monitoring dan evaluasi secara rutin perlu dilakukan agar potensi bahaya logam terhadap biota dan manusia di sekitarnya dapat teridentifikasi. Gambaran distribusi spasial logam pada sedimen laut merupakan salah satu metode yang dapat digunakan dalam memantau konsentrasi logam di sedimen secara menyeluruh. Studi tentang sebaran spasial logam berat pada sedimen perairan pantai kota Makassar menjadi sangat penting dilakukan karena bisa merupakan informasi yang dibutuhkan dalam menganalisis sumber dan dampak pencemaran logam bioavailable. Informasi ini selanjutnya dapat digunakan dalam pemantauan dan evaluasi pencemaran logam oleh pemerintah Kota Makassar. Oleh karena itu penelitian ini bertujuan memperlihatkan sebaran spasial logam total dan fraksi bioavailable $\mathrm{Pb}, \mathrm{Cd}, \mathrm{Cu}$, dan $\mathrm{Zn}$.

\section{METODE PENELITIAN}

\section{Waktu dan Tempat Penelitian}

Perairan pantai Kota Makassar merupakan daerah pantai di Kota Makassar yang paling terkena oleh dampak aktivitas manusia, seperti reklamasi, rekreasi, aktivitas pelabuhan, transportasi, pembuangan akhir limbah dari 13 kanal kota Makassar. Perairan ini juga merupakan muara dari dua sungai besar yaitu sungai Jenebrang dan sungai Tallo. Sampling dilakukan pada beberapa titik sepanjang muara Sungai Jeneberang sampai muara Sungai Tallo (Gambar 1).

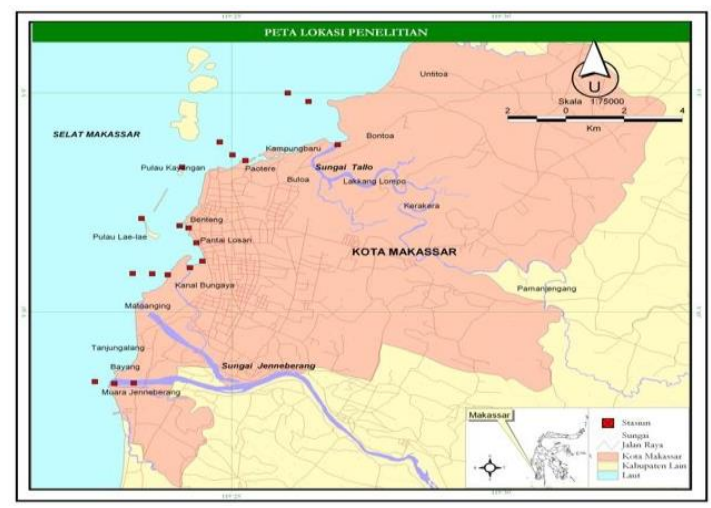

Gambar 1. Lokasi Penelitian

Stasiun ditentukan berdasarkan outlet yang bermuara di perairan pantai Kota Makassar, yaitu: Stasiun 1 adalah Muara Sungai Jeneberang, Stasiun 2 adalah Pantai Tanjung Merdeka (TM), Stasiun 3 adalah Pantai Losari, Stasiun 4 adalah Kanal Benteng, Stasiun 5 adalah Kanal Paotere, Stasiun 6 adalah Muara Sungai Tallo.

\section{Bahan dan Data}

Analisis logam dilakukan pada sedimen yang berukuran $<63 \mu \mathrm{m}$. Peningkatan partikel sedimen halus dengan ukuran $<63 \mu \mathrm{m}$ sejalan dengan peningkatan logam di sedimen, dan umumnya sejalan dengan peningkatan input logam secara antropogenik (Scouller et al., 2006). Contoh sedimen yang diambil hanya pada permukaan sedimen, yaitu bagian oksik dengan kedalaman 1 3 mm, dengan menggunakan van Veen Grab Sampler. Contoh sedimen diambil pada bagian tengah grab untuk mencegah kontaminasi dari bagian logam pada grab sampler, lalu dimasukkan ke dalam kemasan plastik, dan disimpan di dalam cool box selama transportasi. Sebelum proses esktraksi sampel disimpan dalam kantong plastik dan dibekukan dalam freezer pada suhu $-20^{\circ} \mathrm{C}$ untuk mencegah proses biokimiawi yang bisa merusak sampel. Sebelum proses fraksinasi contoh sedimen disaring dalam keadaan kering (dry sieving) untuk mendapatkan fraksi lanau atau silt $(<$ $63 \mathrm{um}$ ). Spesiasi logam dilakukan dengan metode fraksinasi Three-Steps Sequential (Sekuensi Tiga Tahap) yang digunakan oleh Ure et al., (1993) dalam Davidson et al., (1994). Metode fraksinasi dan prosedur kerjanya dapat dilihat pada Tabel 1. 
Konsentrasi total masing-masing logam pada sedimen ditentukan dengan mengekstrak sedimen secara destruksi asam dengan menggunakan pelarut $\mathrm{HNO}_{3}$ (asam nitrat) dan $\mathrm{HClO}_{4}$ (asam perklorat) (SNI 06-06992.8-2004).

Sampel sedimen untuk analisis konsentrasi logam total dan fraksi pada $\mathrm{Pb}, \mathrm{Cd}, \mathrm{Cu}$ dan $\mathrm{Zn}$ dianalisis di Laboratorum Balai Teknik Kesehatan Lingkungan (BTKL), Departemen Kesehatan, Jakarta.
Konsentrasi logam di sedimen dianalisis dgn menggunakan Atomic Absorption Spectrophotometer (Hitachi- Z 2000 Tandem Flame/Furnace AAS) dengan limit of detection (LOD) untuk masing-masing logam adalah : $\mathrm{Pb}$ $\left(0,006 \mathrm{mg} \mathrm{kg}^{-1}\right), \mathrm{Cd}\left(0,001 \mathrm{mg} \mathrm{kg}^{-1}\right), \mathrm{Cu}(0,006 \mathrm{mg}$ $\left.\mathrm{kg}^{-1}\right)$, dan $\mathrm{Zn}\left(0,031 \mathrm{mg} \mathrm{kg} \mathrm{kg}^{-1}\right)$. Pengukuran kosentrasi $\mathrm{Pb}$ dan $\mathrm{Cd}$ menggunakan detektor graphite furnace, sedangkan untuk $\mathrm{Cu}$ dan $\mathrm{Zn}$ digunakan detektor flame

Tabel 1. Metode Ekstraksi Sekuensi Tiga Tahap*

\begin{tabular}{|c|c|c|c|}
\hline Tahap & Fraksi & $\begin{array}{l}\text { Komponen yang } \\
\text { Diekstrak }\end{array}$ & Prosedur \\
\hline 1 & $\begin{array}{l}\text { Terlarut dalam } \\
\text { asam (Acid } \\
\text { Soluble) }\end{array}$ & Ion exchangeable dan karbonat & $\begin{array}{l}40 \mathrm{~mL} \mathrm{CH} 3 \mathrm{COOH} \text { ditambahkan } \\
\text { pada } 1 \text { gram sedimen kering }(<63 \\
\text { um). } 16 \text { jam shaker }\end{array}$ \\
\hline 2 & $\begin{array}{l}\text { Tereduksi } \\
\text { (Reducible) }\end{array}$ & Oksida Fe-Mn & $\begin{array}{l}40 \mathrm{~mL} \text { NH2OH.HCl (pH } 2 \text { dgn } \\
\text { HNO3), } 16 \text { jam shaker }\end{array}$ \\
\hline 3 & $\begin{array}{l}\text { Teroksidasi } \\
(\text { Oxidizible })\end{array}$ & Bahan organik dan sulfit & $\begin{array}{l}10 \mathrm{~mL} \mathrm{H} 2 \mathrm{O} 2,1 \text { jam disgestion, } \\
1 \text { jam water bath, tambahkan } 10 \\
\text { mL } \mathrm{H} 2 \mathrm{O} 2,1 \text { jam water bath, } \\
\text { tambahkan } 50 \mathrm{~mL} \text { CH3COONH4 } \\
\text { (pH } 2 \text { dgn } \mathrm{HNO} 3 \text { ) }\end{array}$ \\
\hline
\end{tabular}

*Sumber: Ure et al., (1993) dalam Davidson et al., (1994)

\section{Analisis Data}

Pola distribusi spasial logam berat ditentukan dengan metode block kriging (BK), menggunakan perangkat Sistem Informasi Geografis (SIG). Penggunaan metode interpolasi BK umum digunakan untuk data kualitas air yang tidak berpola dan bukan merupakan data kontinyus (Burrough, et al. 1998).

\section{HASIL DAN PEMBAHASAN}

\section{Hasil}

Distribusi spasial masing-masing logam $\mathrm{Pb}, \mathrm{Cd}, \mathrm{Cu}$, dan $\mathrm{Zn}$ dapat dilihat pada Gambar 2, dimana gambar tersebut menunjukkan pola sebaran konsentrasi total logam dan fraksi bioavailable-nya (fraksi1, 2 dan 3) di sedimen perairan Kota Makassar. Konsentrasi total $\mathrm{Pb}$ yang tinggi di sekitar Kanal Paotere, Kanal Benteng dan kawasan Pantai Losari. Fenomena ini wajar terjadi sejalan dengan peruntukan Kanal Paotere yang merupakan tempat bermuaranya buangan-buangan kota Makassar. Sedangkan pada lokasi Benteng juga terdapat kanal kecil yang juga mengalir ke pantai. Demikan pula pada lokasi Losari, tepat di samping gedung CCC, merupakan muara dari Kanal Jongaya, yang mengalirkan limbah dari bagian selatan Kota Makassar. Pola spasial $\mathrm{Pb}$ total di sedimen yang tidak merata secara horisontal juga memperlihatkan bahwa input $\mathrm{Pb}$ di perairan pantai Kota Makassar dominan berasal dari daratan dibandingkan dari atmosfir. Akumulasi logam $\mathrm{Pb}$ terlihat lebih tinggi di bagian utara pantai dibandingkan dengan bagian selatan.

Pola sebaran spasial total logam $\mathrm{Cd}$ dan $\mathrm{Cu}$ di sedimen memperlihatkan pola penyebaran yang menyerupai penyebaran $\mathrm{Pb}$, yaitu semakin meningkat dari bagian selatan pantai ke bagian utara, dimana sangat tinggi di lokasi Kanal Paotere dan konsentrasi yang sedang merata dari bagian selatan, muara Sungai jeneberang, hingga utara pantai di Kanal Benteng. Sedangkan sebaran spasial total logam $\mathrm{Zn}$ di sedimen memperlihatkan konsentrasi cukup tinggi pada daerah utara pantai, khususnya Kanal Paotere dan muara Sungai Tallo, juga terlihat konsentrasi cukup tinggi di lokasi Losari.

Konsentrasi logam pada fraksi bioavailable yaitu fraksi 1, 2 dan 3 dapat menunjukkan konsentrasi yang mudah diserap dan bisa menyebabkan dampak bahaya bagi biota. Konsentrasi logam dapat berpindah dari satu fraksi ke fraksi lainnya yang dipengaruhi oleh parameter geokimia sedimen, seperti potensi redoks, kandungan bahan organik, kandungan sulfit, oksida besi/mangan, ukuran butiran dan tekstur sedimen.

Pola spasial fraksi $1 \mathrm{~Pb}$ dan $\mathrm{Cu}$ terlihat berada pada konsentrasi rendah pada semua lokasi penelitian, yaitu dari selatan ke utara pantai kota Makassar. 
Sedangkan $\mathrm{Pb}$ pada fraksi 2 terlihat sangat tinggi disemua lokasi dan tertinggi di bagian utara pantai. Penyebaran $\mathrm{Pb}$ fraksi 3 terlihat tinggi dan terlokalisasi pada Kanal Paotere. Pola spasial konsentrasi $\mathrm{Cu}$ fraksi 2 dan 3 terlihat rendah dan merata dari utara ke selatan pantai, dengan sedikit peningkatan $\mathrm{Cu}$ pada fraksi 3 di lokasi Kanal Paotere. Pola sebaran spasial Cd dan Zn pada fraksi 1 terlihat meningkat konsentrasinya ke arah utara pantai dan tinggi pada lokasi Kanal Paotere.
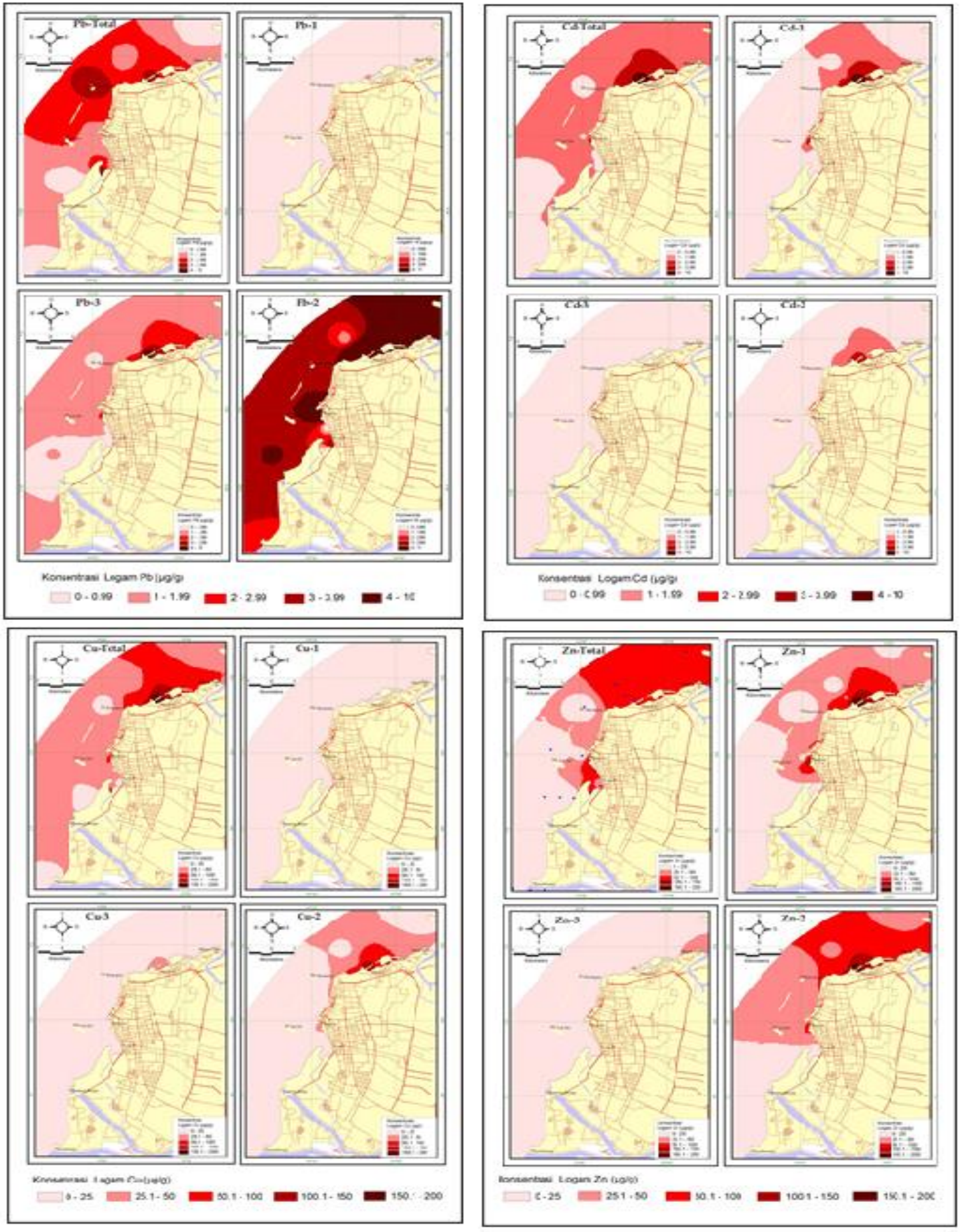

Gambar 2. Sebaran spasial konsentrasi total dan fraksi logam $\mathrm{Pb}, \mathrm{Cd}, \mathrm{Cu}$, dan $\mathrm{Zn}$ di sedimen pantai kota Makassar.
Sedangkan sebaran spasial fraksi 2 dan 3 terlihat berada kisaran konsentrasi rendah dengan peningkatan khususnya pada lokasi Kanal Paotere dan muara Sungai Tallo.

\section{Pembahasan}

Pola penyebaran logam secara spasial pada 20 titik di lokasi penelitian dapat menggambarkan seberapa jauh penyebaran logam $\mathrm{Pb}, \mathrm{Cd}, \mathrm{Cu}$, dan $\mathrm{Zn}$ secara 
horisontal. Pola sebaran spasial polutan pada suatu lokasi geografis sangat penting untuk tujuan monitoring dan pengelolaan. Pola sebaran ini juga dapat digunakan untuk mengidentifikasi sumber polutan (Zhou et al., 2007).

Penelitian Werorilangi (2012), memperlihatkan pola penyebaran faktor pengayaan (Enrichment Factor) yang menunjukkan sumber antropogenik logam $\mathrm{Pb}$, $\mathrm{Cd}, \mathrm{Cu}$, dan $\mathrm{Zn}$ di sedimen perairan pantai Kota Makassar. Pola penyebaran konsentrasi total logam $\mathrm{Pb}, \mathrm{Cu}$, dan $\mathrm{Cd}$ diduga disebabkan oleh input antropogenik yang sedang hingga tinggi pada lokasi penelitian, hal ini ditunjukkan oleh pola penyebaran Faktor Pengayaan (EF) ketiga logam tersebut (Gambar 3). Terlihat pula, logam $\mathrm{Cu}$ yang mendapat inputan antropogenik paling tinggi pada

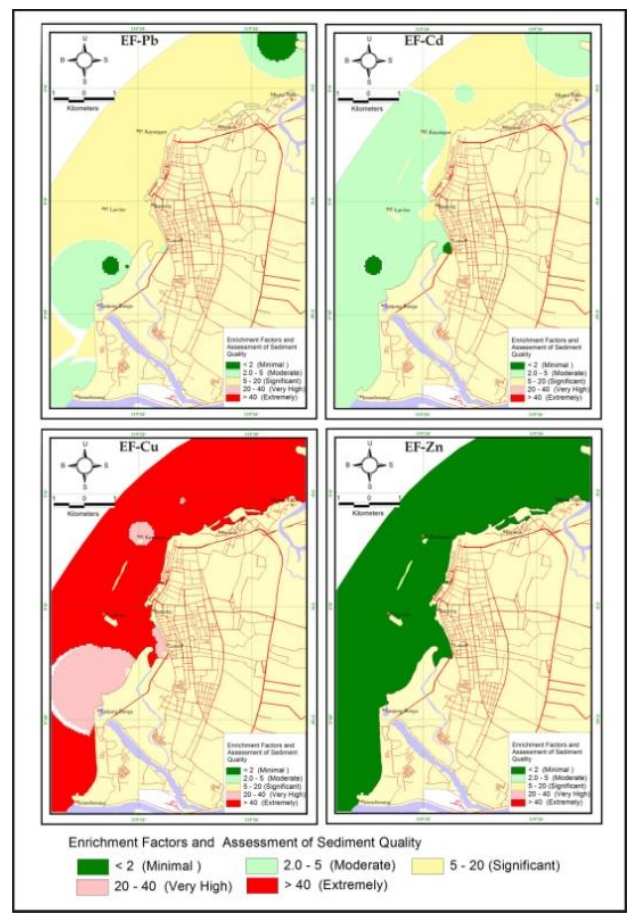

lokasi penelitian, dari selatan hingga utara pantai Kota Makassar. Sepanjang perairan pantai Kota Makassar terdapat beberapa pelabuhan rakyat yang diduga menyumbangkan $\mathrm{Cu}$ yang berasal dari cat antifouling yang digunakan pada kapal. Terutama pada lokasi Paotere tempat bermuara Kanal Panampu yang mengalirkan hampir seluruh buangan kota Makssar baik dari utara kota maupun dari selatan kota. Sedangkan lokasi muara Sungai Tallo kemungkinan menyumbangkan logam yang berasal dari limbah industri Kawasan Industri Makassar (KIMA) yang berlokasi di sekitar Sungai Tallo. Terlihat pola penyebaran total $\operatorname{logam} \mathrm{Zn}$ tidak sejalan dengan input antropogenik, nilai EF rendah dan merata pada semua lokasi. Hal ini diduga disebabkan oleh anomali data penelitian.

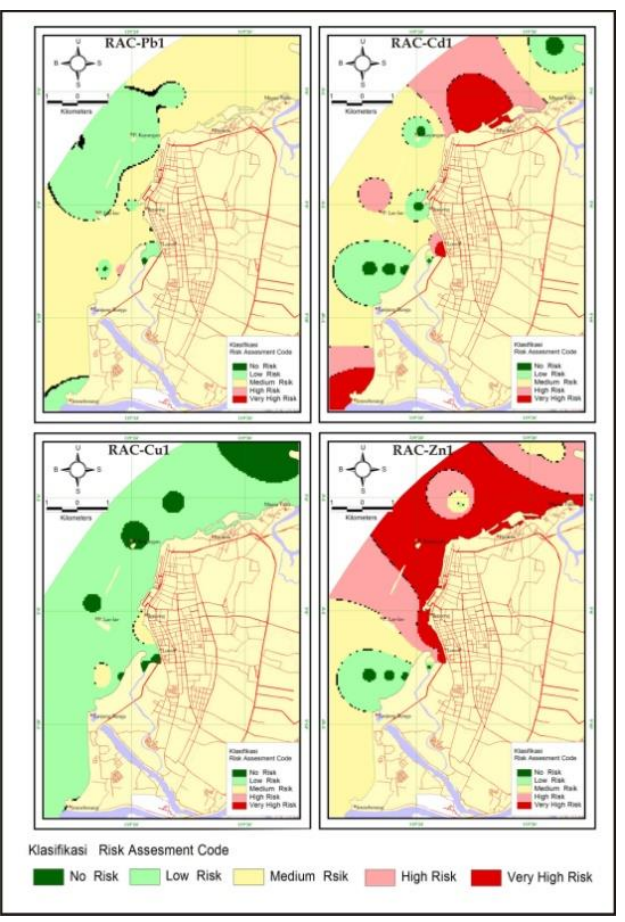

Gambar 3. Sebaran nilai Faktor Pengayaan (EF) dan Risk Assesment Code (RAC) logam $\mathrm{Pb}, \mathrm{Cd}, \mathrm{Cu}$, dan $\mathrm{Zn}$ di sedimen pantai kota Makassar (sumber: Werorilangi, 2012).

Spesiasi logam di sedimen sangat menentukan ketersediaannya (bioavailability) bagi biota. Logam pada fraksi 1, 2 , dan 3 adalah logam yang labil, dimana pergerakannya sangat dipengaruhi oleh kondisi lingkungan. Logam pada fraksi 1 merupakan logam paling tinggi mobilitasnya (most available form) karena paling mudah bertukar (most exchangeable) dan perikatannya sangat lemah (weakly adsorbed) pada matriks sedimen sehingga paling mudah lepas dan larut dalam kolom air dan oleh karena itu merupakan fraksi yang paling tersedia dan berpotensi diserap serta bisa menimbulkan toksisitas pada organisme perairan (Zimmerman dan Weindorf, 2010; Sundaray et al., 2011). Berturut-turut fraksi yang mobilitasnya paling tinggi ke rendah adalah fraksi $1>$ fraksi2> fraksi 3 .

Hasil penelitian spesiasi menunjukkan bahwa logam di sedimen berikatan pada fraksi yang berbeda dengan kekuatan ikatan yang juga berbeda. Perbedaan ikatan tersebut mengindikasikan reaktivitas sedimen serta dapat digunakan untuk menilai risiko bahaya yang ditimbulkan oleh logam di lingkungan perairan. Dalam menilai risiko 
tersebut, suatu indeks penilaian risiko, yaitu Risk Asessessment Code (RAC) digunakan dalam penilaian ketersediaan (availabilitas) logam di sedimen dengan mengaplikasikan suatu skala pada nilai persentasi logam di fraksi exchangeable dan karbonat (Honglei et al., 2008; Sundaray et al., 2011). Hal ini penting karena logam yang berasal dari aktivitas antropogenik adalah umumnya bersifat adsorptif, dapat bertukar (exchangeable) dan berikatan dengan fraksi karbonat. Logamlogam tersebut perikatannya lemah sehingga dapat larut dalam kolom air dan terserap oleh biota (Singh et al., 2005).

Terdapat perbedaan pola penyebaran fraksi logam di lokasi penelitian. Pola penyebaran fraksi logam $\mathrm{Pb}$ dan $\mathrm{Cu}$ tidak sejalan dengan tingginya input antropogenik dan didominasi secara berturut-turut oleh fraksi 2>fraksi 3>fraksi 1. Sedangkan Pola penyebaran logam $\mathrm{Cd}$ dan $\mathrm{Zn}$ terdapat kemiripan, dimana pola penyebarannya didominasi oleh fraksi $1>$ fraksi $2>$ fraksi 3 dan sejalan dengan tingginya input antropogenik dari arah selatan ke utara kota Makassar. Pola penyebaran logam serta hasil pemetaan nilai RAC fraksi logam $\mathrm{Pb}, \mathrm{Cd}, \mathrm{Cu}$, dan $\mathrm{Zn}$ (Gambar 3), mengindikasikan $\mathrm{Zn}$ dan $\mathrm{Cd}$ memiliki potensi bioavailibilitas yang tinggi (berisiko tinggi), serta memperlihatkan adanya tren penyebaran proporsi fraksi 1 yang semakin mengecil dengan semakin menjauh dari input antropogenik.

Terdapat fenomena yang menarik jika membandingkan pola penyebaran logam berdasarkan nilai EF dan RAC, dimana jika berdasarkan input antropogenik (EF), terlihat tren pengayaan logam $\mathrm{Cu}$ dan $\mathrm{Pb}$ pada hampir seluruh lokasi, sedangkan jika berdasarkan RAC, pola tersebut tidak ditemukan pada logam tersebut, tetapi justru nilai RAC tinggi pada logam lainnya, yaitu $\mathrm{Cd}$ dan Zn. Perbedaan tersebut mengindikasikan bahwa konsentrasi logam total tidak selalu sejalan dengan proporsi logam pada fraksi bioavailble.

Adanya indikasi peningkatan konsentrasi logam $\mathrm{Pb}$, $\mathrm{Cd}$, dan $\mathrm{Cu}$ yang berasal dari sumber antropogenik serta terdeteksinya konsentrasi logam $\mathrm{Cd}$ dan $\mathrm{Zn}$ pada fraksi most bioavailable (fraksi 1) di bagian utara perairan pantai Kota Makassar menunjukkan potensi terjadinya pencemaran dan bisa mengakibatkan dampak biologis serta ekologis pada biota perairan serta manusia di sekitarnya. Sehingga pengelolaan wilayah perairan pantai bagian utara merupakan hal yang penting. Pengelolaan tersebut harus meliputi minimalisasi asupan logam yang masuk ke wilayah perairan seperti di 1) Sungai Tallo yang berasal dari limbah industri terutama dari Kawasan Industri Makassar (KIMA); 2) wilayah perairan Paotere yang berasal dari limbah rumah tangga dan aktivitas pelabuhan; 3) perairan Benteng yang berasal dari limbah aktivitas pelabuhan; dan 4) wilayah perairan Losari yang berasal dari limbah rumah tangga dan limbah rumah sakit. Pengadaan instalasi pengelolaan air limbah (IPAL) pada lokasilokasi tersebut juga merupakan urgensi dari sistem pengelolaan wilayah pesisir Kota Makassar.

Beberapa hasil penelitian menunjukkan bahwa aktivitas pengerukan (dredging) dan reklamasi pantai dapat menyebabkan perubahan karakter fisik, kimia dan biologi sedimen yang bisa meremobilisasi logam antara kolom air dan sedimen (Hall, 1989; Chen and Jiao, 2008). Meningkatnya aktivitas pembangunan di bagian selatan pantai Kota Makassar (Pantai Losari) berpotensi meningkatkan konsentrasi logam di kolom air sehingga kemungkinan dapat menyebabkan dampak berbahaya bagi biota, terutama yang hidup di bagian dasar.

Hasil penelitian Werorilangi, et al. (2014) juga mengungkapkan tingginya akumulasi logam pada biota kekerangan terutama yang ditemukan di bagian selatan perairan pantai Kota Makassar. Tingginya konsentrasi logam pada kekerangan di bagian selatan pantai terutama di lokasi Tanjung Merdeka dan Losari menunjukkan akumulasi logam pada biota tidak selalu dipengaruhi oleh input yang besar yang masuk ke perairan tetapi juga dipengaruhi oleh kondisi fisik dan kimia kolom air dan sedimen yang dapat mengubah bentuk spesiasi logam. Hal ini sejalan dengan hasil penelitian Hendozko, et al. (2010) yang menyatakan terdapat korelasi antara fraksi labil logam Cd, Zn, dan Fe di sedimen dengan penyerapan dan bioakumulasi pada jaringan lunak kerang Macoma balthica. Sehingga dalam melakukan Risk Assessment pencemaran logam juga harus mempertimbangkan penilaian kondisi fisik dan kimia kolom air serta sedimen, selain mengidentifikasi sumber logam.

Implikasi lain dari tingginya konsentrasi logam pada kekerangan yang ditemukan di bagian selatan pantai Kota Makassar adalah terkait dengan food safety. Proses bioakumulasi dan proses biomagnifikasi dalam rantai makanan dapat menyebabkan peningkatan konsentrasi logam pada level tropik yang rendah ke level tropik yang tinggi. Oleh karena itu penduduk disarankan untuk tidak mengonsumsi kekerangan yang berasal dari bagian selatan pantai Kota Makassar atau melakukan depurasi, seperti mengekspose kekerangan dengan aliran air yang bersih.

\section{KESIMPULAN}

Sebaran spasial logam $\mathrm{Pb}, \mathrm{Cd}, \mathrm{Cu}$, dan $\mathrm{Zn}$ di sedimen meningkat ke arah utara pantai Kota Makassar. Sebaran logam sangat ditentukan oleh 
input atau sumber dari daratan. Pola sebaran spasial fraksi 1 logam $\mathrm{Pb}$ dan $\mathrm{Cu}$ tidak berbanding lurus dengan pola sebaran konsentrasi totalnya di sedimen. Sedangkan pola sebaran spasial fraksi 1 logam $\mathrm{Cd}$ dan $\mathrm{Zn}$ berbanding lurus dengan pola sebaran konsentrasi totalnya di sedimen.

Dalam melakukan Risk Assessment selain mengukur konsentrasi total logam, juga harus mempertimbangkan fraksi logam yang mempunyai mobilitas dan bioavailibilitas yang tinggi, terutama pada fraksi 1 .

Terindikasi telah terjadi peningkatan asupan logam dari sumber antropogenik serta fraksi yang mudah diserap oleh organisme (bioavalaible) pada logam $\mathrm{Pb}, \mathrm{Cd}$, dan $\mathrm{Zn}$ di sedimen perairan Kota Makassar, sehingga dalam pengelolaan wilayah pesisir sangat perlu dilakukan pengawasan input logam, yaitu pengawasan pengelolaan limbah terutama pada point source, serta upaya penggunaan cat antifouling yang ramah lingkungan.

\section{DAFTAR PUSTAKA}

Bapedalda. 2007. Sertifikat Hasil Uji. Pengawasan dan Pemantauan Kualitas Lingkungan Hidup Propinsi Sulawesi Selatan Tahun 2007. Bapedalda Propinsi Sulawesi Selatan. Makassar.

Bapedalda. 2008. Sertifikat Hasil Uji. Pengawasan dan Pemantauan Kualitas Lingkungan Hidup Propinsi Sulawesi Selatan Tahun 2008. Bapedalda Propinsi Sulawesi Selatan. Makassar.

Chen, K., and J.J. Jiao. 2008. Metal concentrations and mobility in marine sediment and groundwater in coastal reclamation areas: A case study in Shenzhen, China. Environmental Pollution, 151: 576 - 584.

Cunha, L., A. Amaral, V. Medeiros, G. M. Martins, F. Wallenstein, R.P. Couto, A.I Neto, \& A. Rodriques. 2008. Bioavalibility metals and cellular effects in the digestive gland of marine limpets living close to swallow water hydrothermal vents. Chemosphere, 71:13561362.

Davidson, C.M., R.P. Thomas, S.E. McVey, R. Perala, D. Littlejohn, and A.M. Ure. 1994. Evaluation of a sequential extraction procedure for the speciation of heavy metals in sediments. Analy. Chemi. Acta, 291: $277-$ 286.

Hall, L.A. 1989. The Effects of Dredging and Reclamation on Metal Levels in Water and Sediments from an Estuarine Environment off Trinidad, West Indies. Environmental Pollution, 56 :189-207.

Hendozko, E., P.Szefer, \& J. Warzocha. 2010. Heavy metals in Macomabalthica and extractable metals in sediments from the southern Baltic Sea. Ecotoxicology and Environmental Safety, 73: 152-163.

Honglei, L., L. Liqing, Y. Chengqing, and S. Baoqing. 2008. Fraction distribution and risk assessment of heavy metals in sediments of Moshui Lake. Journal of Environmental Sciences, 20: 390-397.

Paller, M.H., and A.S. Knox. 2013. Bioavailability of metals in contaminated sediments. E3S Web of Conference, 1, 02001.

Rizal, M. 2011. Kandungan logam berat $\mathrm{Cu}$ dan $\mathrm{Pb}$ pada lamun Enhalus acoroides di perairan Kepulauan Spermonde. Skripsi. Program Studi Ilmu Kelautan. Jurusan Ilmu Kelautan. Fakultas Ilmu Kelautan dan Perikanan. Universitas Hasanuddin.Makassar.

Roem, M., 2007. Distribusi Pb pada beberapa organ ikan kakap putih (Lates calcarifer, Bloch, 1890) dari perairan muara Sungai Karajae Pare-Pare dan muara Sungai Tallo Makassar. Skripsi. Program Studi Ilmu Kelautan. Jurusan Ilmu Kelautan. Fakultas Ilmu Kelautan dan Perikanan. Universitas Hasanuddin.Makassar.

Samawi, M.F. 2007. Desain Sistem Pengendalian Pencemaran Perairan Pantai Kota (Studi Kasus Perairan Pantai Kota Makassar). Disertasi. Sekolah Pascasarjana. Institut Pertanian Bogor.

Scouller, R.C., I.Snape, J.S. Stark, dan D.B. Gore. 2006. Evaluation of geochemical methods for discrimination of metal contamination in Antarctic marine sediments: A case study from Casey Station. Chemosphere, 65 : 294309.

Singh, K. P., Mohan, D., Singh, V. K. and Malik, A. 2005. Studies on distribution and fractionation of heavy metals in Gomti river sediements-a tributary of the Ganges, India. J. Hydro., 312: 14-27.

Stauber, J.L., S. Andrabe, M. Adams, and J.A. Correa. 2005. Copper biovailability in coastal environment of Nothern Chile : comparisons of bioassay and analytical speciation approaches. Marine Pollution Bulletin, 50 : 1363-1372. 
Sundaray, S. K., B. B. Nayak, S. Lina, and D. Bhatta. 2011. Geochemical speciation and risk assessment of heavy metals in the river estuarine sediments. A case study: Mahanadi basin, India. Journal of Hazardous Materials, 186 : 1837-1846.

Ure, A.M., Quevauviller, H. Muntau, and B. Griepink. 1993. Speciation of heavy metals in solids and harmonization of extraction techniques undertaken under the auspices of the BCR of the Commission of the European Communities. Int. J. Environ. Anal. Chem., $51,135-142$.

Widyasari, A., 2007. Analisis pencemaran logam berat : timbel dan kadmium kaitannya dengan karakter ekologi makrozoobentos dan bioindikator di beberapa muara sungai Propinsi Sulawesi Selatan. Skripsi. Program Studi Ilmu Kelautan. Jurusan Ilmu Kelautan. Fakultas Ilmu Kelautan dan Perikanan. Universitas Hasanuddin. Makassar.

Werorilangi, S., 2012. Spesiasi logam: bioavailabilitas bagi biota bentik dan pola sebaran spasial di sedimen perairan pantai Kota Makassar. Disertasi. Program Studi Ilmu Pertanian. Program Pascasarjana. Universitas Hasanuddin. Makassar.

Werorilangi, S., A. Tahir, A. Noor, dan M.F. Samawi, 2013. Status pencemaran dan potensi bioavailabilitas logam di sedimen perairan pantai kota makassar. Prosiding Seminar Nasional Tahunan X Hasil Perikanan dan Kelautan. UGM. Yogyakarta.

Werorilangi, S., A. Tahir, A. Noor, and M.F. Samawi, 2014. Relationship Between The Bioavailability of Sediment-Bound Metals and Their Concentrations in Benthic Invertebrates. Proceeding on "International and National Conference" on Climate Change, Marine Life, and Livelihoods in the Center of Coral Triangle. Hasanuddin University. Makassar. Indonesia.

Wulandari, S., 2008. Konsentrasi logam berat Pb, $\mathrm{Cd}$ dan $\mathrm{Cu}$ pada berbagai ukuran kerang dasah (Anadara granosa) di perairan Teluk Losari Makassar. Skripsi. Program Studi Ilmu Kelautan. Jurusan Ilmu Kelautan. Fakultas Ilmu Kelautan dan Perikanan. Universitas Hasanuddin.Makassar.

Zhou, F., H. Guo, dan Z. Hao, 2007. Spatial Distribution of heavy metals in Hong Kong's marine sediments and their human impacts :
A GIS-based chemometric approach. Mar Poll Bulletin, 54: 1372-1384.

Zimmerman, A.J., and D.C. Weindorf. 2010. HeavyMetal and TraceMetal Analysis in Soil by Sequential Extraction: A Review of Procedures. International Journal of Analytical Chemistry, Volume 2010, 7 pages. 